\title{
要養護児童のためのグループホーム整備の実態に関する研究 A STUDY ON THE GROUP HOME FOR CHILDREN IN RESIDENTIAL CARE
}

\author{
石 垣＼cjkstart文*, 小野田 泰明**, 松 浦 真 樹***, 金 成 瑞 穂**** \\ Aya ISHIGAKI, Yasuaki ONODA, Masaki MATSUURA \\ and Mizuho KANNARI
}

\begin{abstract}
The purpose of this study is to examine the actual condition of group home for children in residential care, and to clarify issues of the living environment. The main findings are as follows:

1) There are 194 group homes throughout Japan.

2) The types of the living environment are characterized by its property, the size of the housing and the member of the group homes. Not all the group homes afford enough space for the children and the staff.

3) The difference in living environment comes also from finances and child welfare policy in each local autonomy.
\end{abstract}

Keywords: residential center, group home, actual condition, group members, living environment, system 巟童養護施設，グループホーム，整備実態，生活集団，居住環境，制度

\section{1. 研究の背景}

児童虐待問題や青少年の荒れなど、今日の览童と家庭を巡る状況 には多くの困難がみられる。その一方で公的な福祉支援は先細り、 所得格差も増大の傾向にあるなど、その重要性にも関わらず、児童・ 家庭に対する支援体制の構築や人生初期における保障の確立 ${ }^{1,2)}$ は ますます困難となっている注1)

様々な事情から家族と暮らすことのできない要養護児童は、現在、 4 万人に達しており、その 9 割程度が施設での生活を送っている。 そうした施設の中心的役割を担ってきたのが览童養護施設であるが、 近年は入所児童や家族の抱える問題の多様化・深刻化に直面寸るな ど転換期を迎えている。様々な実践や研究によって、児童の自立に 際した課題が明らかにされつつある ${ }^{3,4)}$ ものの、施設・行政ともに それを支えるに充分な方策が取られてきたとは言い難い状況にあっ た。そのようななか、近年、小規模の生活集団が施設の外で暮らす「グ ループホーム ( 以下、GHと略す)」が、児童へのより家庭的な生活 やケアを提供できる方策として期待されている。

一方、現在のわが国の福祉体制全体に視線を転ずると ${ }^{5)}$ 「ソーシャ

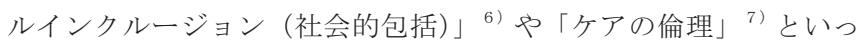
た点からの社会再構築の必要性が指摘される他、実際に政府が人々 へ「参加型福祉社会」への要請 ${ }^{8)}$ を行うなど福祉国家レジームの転
換期にあるといえる。他方、そうした活動を担ってきた子育て世代 に経済活動への参加を奨励する注2) といった相反する状況もみられる なか、児童の育成や地域社会のあり方にも大きな影響を及ぼす $\mathrm{GH}^{9)}$ は極めて重要な枠組みといえる。

さて、1960 年代からの先駆的な取り組みがみられた $\mathrm{G} \mathrm{H}^{10)}$ は、85 年全国で初めて東京都で、次いで横浜市で制度化され、その後 92 年 に高齢児童の自立支援目的に活用されるという経緯をたどってきた。 しかし全国的な制度は、2000 年（地域小規模児童養護施設の制度化） を待たなければならなかった。生活集団の小規模化による意義やそ の試みが示されつつある現在 ${ }^{11,12,13)}$ 、巟童養護施設の将来構想の柱 となる養育形態 ${ }^{14)}$ とされるGHであるが、その整備や住環境に対す る研究は必ずしも十分とは言えなかったのである注3)。国の制度開始 に前後して、社会福祉分野からは G Hの整備状況や入所児童の特性 が示されてきた ${ }^{15,16)} も の の 、$ 近年の整備数の増加を捉えた基礎的な データベースはなく、生活集団の実態や建築特性、また現在の G H 事業が抱える課題についてもほとんど手つかずのままであった。

\section{2. 研究の目的}

そこで本研究では、全国 GHの整備実態を把握し、その基礎的デー タベースの構築を通じて日本における G H 整備の特色とその課題を

\footnotetext{
本稿は2007，2008年度日本建築学会大会学術講演会，2007年度日本社会福祉学会全国大会，2007年度日本子ども家庭福祉学会全国大会での発表内容に加筆修正を加えたもので ある。

早楥田大学人間科学学術院 助手・博十(丁学)

** 東北大学大学院工学研究科 教授 - 博士 (工学)

*** (株)竹中工務店 工修

**** 積水八ウス株) 工修
} 
明らかにすることを目的とし、具体的には以下の四構成をとる。まず、 全国の GHの整備状況ならびに各 GHの実施主体の特色を明らかに する。ついで、そこでの児童及び職員の集団構成の特徴を把握する とともに、建築的な特性についても明らかにする。最後に得られた 知見を統合して、GH整備における問題状況を整理する。

\section{3. 研究の方法}

\section{1. 研究の対象}

現在のわが国では、要養護児童のための G Hを包括する制度はみ られない。そこで本研究では、GHを以下の(1)一(4)のいずれかに該

表 1 調查の概要

\section{[調査 1 グループホームの整備数調査] \\ 対象：全国 62 自治体主管課（47 都道府県、15 政令指定都市） \\ 方法 : アンケート郵送調査 \\ 期間 : 2006.8.1 1 発送、2006.9.19 反切 \\ 回収率：98\%（61/62 自治体） \\ [調査 2 アンケート作成へ向けたヒアリング調查] \\ 対象：先駆的に GHを展開してきた 3 施設 GHの制度化に関わった福祉行政職員 1 名}

内容：GHの数と事業名、各 $\mathrm{GH}$ の運営法人・所属本体施設名、各 $\mathrm{GH}$ の住所（可 能な場合)、自治体独自制度の有無とその理由（有の場合は要綱を添付）

[調査 3 グループホームの実態調査 $]$

対象：198 GH（自治体への調査から把握された $194 \mathrm{GH}$ と、独自に把握された $4 \mathrm{GH})$

方法:アンケートの配布調査 ( $43 \mathrm{GH}$ ○は小舎制養育研究会研修会会場にて配布)、 または郵送調査（151 G H、本体施設を通して調査紙を配布し、返信は本体 施設を通さず、各 $\mathrm{GH}$ から直接返送)

内容：建物概要、担当職員および入所児童の属性、担当職員および入所児童と地 域との関係、担当職員による地域の評価、建物平面図の回収

期間：200610.11 配布・発送、2006.11.11 切（人切までに回答がなかった 76 施設には 2006.11.30を人切とする督促状とアンケート用紙を再送)

回収率：69.2\%（137/198 G H、うち 6 G Hは事前に把握していないG Hから の回答) 注 4

表2 GH事業の比較

\begin{tabular}{|c|c|c|c|c|c|c|c|c|}
\hline & & 設置数 & 制度開始 & 経営主体 & 定員 & 設備 & 職員 & その他 \\
\hline \multirow{3}{*}{\multicolumn{2}{|c|}{$\begin{array}{l}\text { 地域小規模 } \\
\text { 児童養護施設 }\end{array}$}} & \multirow{3}{*}{$\begin{array}{c}106 \\
(54.6 \%)\end{array}$} & \multirow{3}{*}{ 2000年 } & \multirow{3}{*}{$\begin{array}{l}\text { すでに本体施設を } \\
\text { 運営している地方 } \\
\text { 公共団体及び社会 } \\
\text { 福祉法人等 }\end{array}$} & \multirow{3}{*}{$\begin{array}{l}\text { 本体施設とは別 } \\
\text { にこ6名 (常に現 } \\
\text { 員5名を下回ら } \\
\text { ないこと) }\end{array}$} & $\begin{array}{l}\text { 児童居室は一人当たり } 3.3 \mathrm{~m}^{2} \\
\text { 以上、居室 } 2 \text { 名まで }\end{array}$ & $\begin{array}{l}\text { 専任の児童指導員又は保育士を } \\
2 \text { 人 }\end{array}$ & $\begin{array}{l}\text { ひとつの本体施設に複数設置可。地域小規模 } \\
\text { と自活訓練は同時認可されいい }\end{array}$ \\
\hline & & & & & & \multirow{2}{*}{ 児童の相互交流の場を有する } & \multirow[t]{2}{*}{ 必要に応じその他職員 (非常勤可) } & 長期にわたり家庭復帰が見込めない児童等 \\
\hline & & & & & & & & 単年度申請 \\
\hline \multirow{3}{*}{\multicolumn{2}{|c|}{$\begin{array}{l}\text { 児童養護施設 } \\
\text { 分園型 } \\
\text { 自活訓練事業 }\end{array}$}} & \multirow{3}{*}{$\begin{array}{c}32 \\
(16.5 \%)\end{array}$} & \multirow{3}{*}{ 1992年 } & & \multirow[t]{3}{*}{ 定員内で6名程度 } & 男女の居室を別に & & \multirow{2}{*}{$\begin{array}{l}\text { ひとつの本体施設に地域小規模と自活訓練 } \\
\text { は同時認可されない }\end{array}$} \\
\hline & & & & & & 一居室の定員は概称二人 & & \\
\hline & & & & & & 必要に応じ個室を設ける & & 一年以内に社会的自立を予定する旧童を優先 \\
\hline \multirow{10}{*}{$\begin{array}{l}\text { 自 } \\
\text { 治 } \\
\text { 㶱 } \\
\text { 自 } \\
\text { 制 } \\
\text { 度 }\end{array}$} & \multirow{4}{*}{$\begin{array}{l}\text { 東京都養護 } \\
\text { 皆童グループ } \\
\text { ホーム制度 }\end{array}$} & \multirow{4}{*}{$\begin{array}{c}42 \\
(21.6 \%)\end{array}$} & \multirow{4}{*}{ 1985年 } & \multirow{4}{*}{$\begin{array}{l}\text { すでに本体施設を } \\
\text { 運営する社会福祉 } \\
\text { 法人等 }\end{array}$} & \multirow{4}{*}{$\begin{array}{l}\text { 定員内飞概ね6 } \\
\text { 名(常に現員 } 5 \\
\text { 名を回らない } \\
\text { こと) }\end{array}$} & \multirow{2}{*}{$\begin{array}{l}\text { 児童福祉施設最低基準に準ず } \\
\text { るもの }\end{array}$} & 児童指導員又は保育士 & ひとつの本体施設に複数設置可 \\
\hline & & & & & & & 男女各1名 & 家賃補助あり \\
\hline & & & & & & 一居室 2 名まで & 必要に応じその他職員（非常勤可） & 単年度申請ではない \\
\hline & & & & & & 児童の相互交流の場を有する & & \\
\hline & & \multirow{3}{*}{$\begin{array}{c}2 \\
(1.0 \%)\end{array}$} & \multirow{3}{*}{ 1985年 } & \multirow[t]{3}{*}{ 社会福祉法人 } & \multirow{3}{*}{\begin{tabular}{|l|} 
定員内て概ね6 \\
名程度
\end{tabular}} & \multirow[t]{3}{*}{ ごく自然な一般家庭と同じ } & \multirow{3}{*}{$\begin{array}{l}\text { 児童と起居を共にし、専門的知 } \\
\text { 識と経唤を有すること }\end{array}$} & ひとつの本体施設に複数設置可 \\
\hline & \multirow{2}{*}{$\left|\begin{array}{c}\text { 僙港市 } \\
\text { アアミリー } \\
\text { グループホーム }\end{array}\right|$} & & & & & & & 家賃補助あり \\
\hline & & & & & & & & 単年度申請ではない \\
\hline & \multirow{3}{*}{$\begin{array}{c}\text { 埼玉県 } \\
\text { 地域小規模 } \\
\text { 枈童養護施設 }\end{array}$} & \multirow{3}{*}{$\begin{array}{c}2 \\
(1.0 \%)\end{array}$} & \multirow{3}{*}{ 2001年 } & \multirow{3}{*}{$\begin{array}{l}\text { すでに本体施設を } \\
\text { 運営している地方 } \\
\text { 公共団体及び社会 } \\
\text { 福祉法人等 }\end{array}$} & \multirow{3}{*}{\begin{tabular}{|l} 
本体施設とは別 \\
にこ6名(常に現 \\
買5 名を下回ら \\
ないこと)
\end{tabular}} & $\begin{array}{l}\text { 児童居室は一人当たり } 3.3 \mathrm{~m}^{2} \\
\text { 以上、一居室 } 2 \text { 名まで }\end{array}$ & 児童指導員又は保育士を 2 人 & ひとつの本体施設に自活訓練との重複可 \\
\hline & & & & & & \multirow[t]{2}{*}{ 児童の相互交流の場を有する } & \multirow[t]{2}{*}{ 必要に応じその他職員 (非常勤可) } & 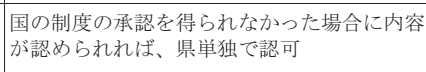 \\
\hline & & & & & & & & 長期にわたり家庭復帰が見込めない児童等 \\
\hline & $\begin{array}{l}\text { 法人独自の } \\
\text { 疷ーム }\end{array}$ & $\begin{array}{c}8 \\
(4.1 \%)\end{array}$ & \multicolumn{6}{|c|}{ 各法人による } \\
\hline & ほか & $\begin{array}{c}2 \\
(1.0 \%)\end{array}$ & & & & 小規模グループ & ケア事業を運用 & \\
\hline
\end{tabular}

設置数は調查 1 より得られた值である。表は、「地域小規模児童養護施設の設置運営について」「東京都養護児童グループホーム制度実施要綱」「埼玉県地域小規模児童養護 施設設置運営要綱」「横浜市ファミリーグループホーム実施補助要綱」「第一回今後目指寸べき児童の社会的養護体制に関する構想検討会資料」上り作成した。神奈川県から は自治体制度の要綱が得られなかった。 設、(2)児童養護施設分園型自活訓練事業、(3)自治体が独自に定めた 地域小規模児童養護施設と同趣旨のもの、(4)施設が独自に展開する 地域小規模児童養護施設と同趣旨のもの)。

\section{2. 調査の概要}

整備状況の把握は次の三段階（表 1) で構成される。まずGHの 整備数を把握するため、全国 62 の自治体主管課に対してアンケート 郵送調查を展開した。次いで行うヒアリングをもとにアンケートを 作成し、自治体より把握された GHへ実態調査を行った。

\section{4. 全国のグループホーム整備状況}

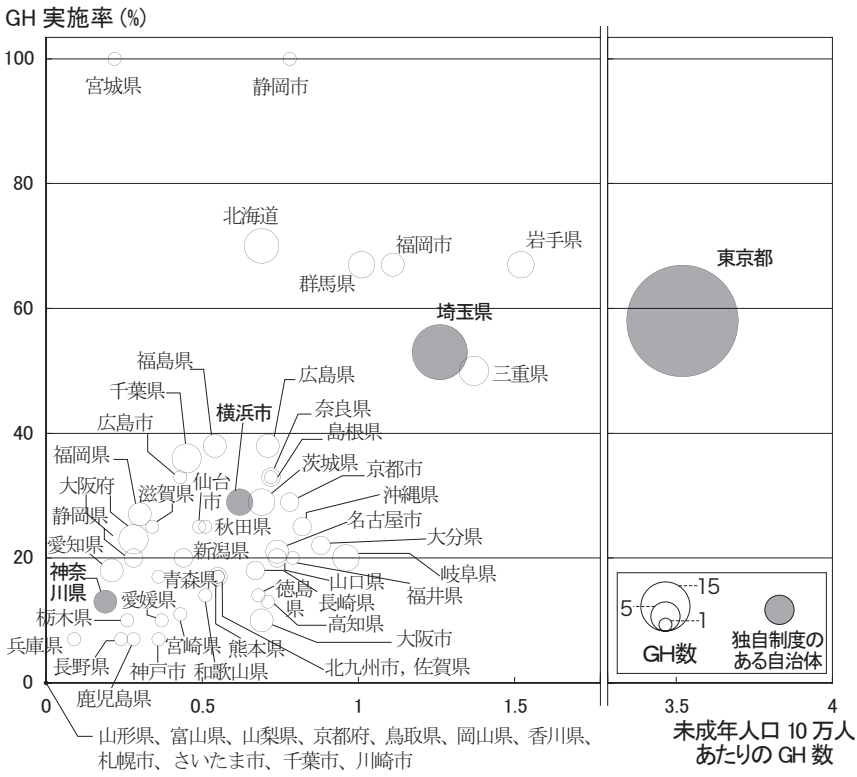

図 1 自治体別にみる GH 整備 注6)
当するものをその対象とすることとした（11地域小規模児童養護施 
览童養護施設（以下、本体施設とも略寸）の $25 \%(139 / 549$ 施設 注5) ) がGHを開設しており、GHの総整備数は 194 である。ひとつ の本体施設が有する G H 数は、 1 が約八割、 2 が約一割であり、最 多で 6 という施設が確認された。2000 年の地域小規模児童養護施設 （以下、「地域小規模」と略寸）の制度化以降、その数は増加している。 また、その増加数では 04 年度が大きくなっているが、これは「地域 小規模」が児童福祉施設等の施設整備費の対象とされた年度である ことが背景にあると推測される。

自治体ごとの整備を見る（図 1 ) と、八割以上の自治体で未成年 人口 10 万人あたりの GH数が 1 未満、GH実施率（当該自治体にお ける児童養護施設数に対し実施施設数の占める割合）は四割未満で、 約二割の自治体においてGHは実施されていなかった。事業種別（表 2 ）では、「地域小規模」が五割強、次いで自治体制度によるものが 挙げられ、両者をあわせると八割近くを占めている。一方で調査 3 によると、児童養護施設分園型自活訓練事業（以下、「自活訓練事業」 と略す）の新設は、03 年度以降は確認されず、GHが、自立を眼前

表 3 地域小規模の開設延期の理由

$(n=66)$

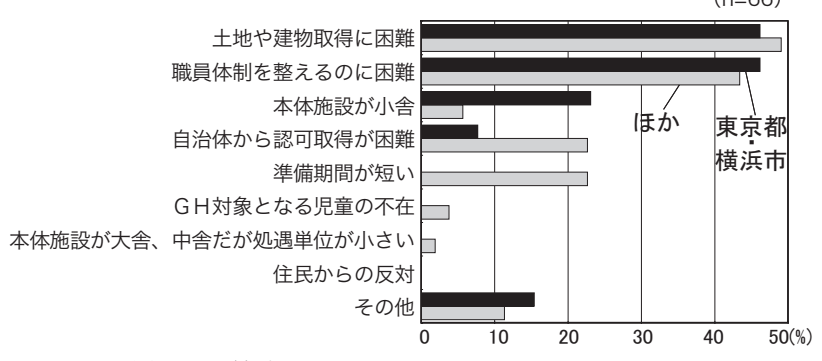

表 4 判別分析の正答率

\begin{tabular}{|l|r|r|r|}
\hline & \multirow{2}{*}{ 施設数 } & \multicolumn{2}{|c|}{ 判別結果 } \\
\cline { 3 - 4 } & & GH非設置施設 & GH設置施設 \\
\hline GH非設置施設 & 408 & 350 & 58 \\
\hline$G H$ 設置施設 & 140 & 36 & 104 \\
\hline
\end{tabular}

表 5 設置主体別にみるGH整備

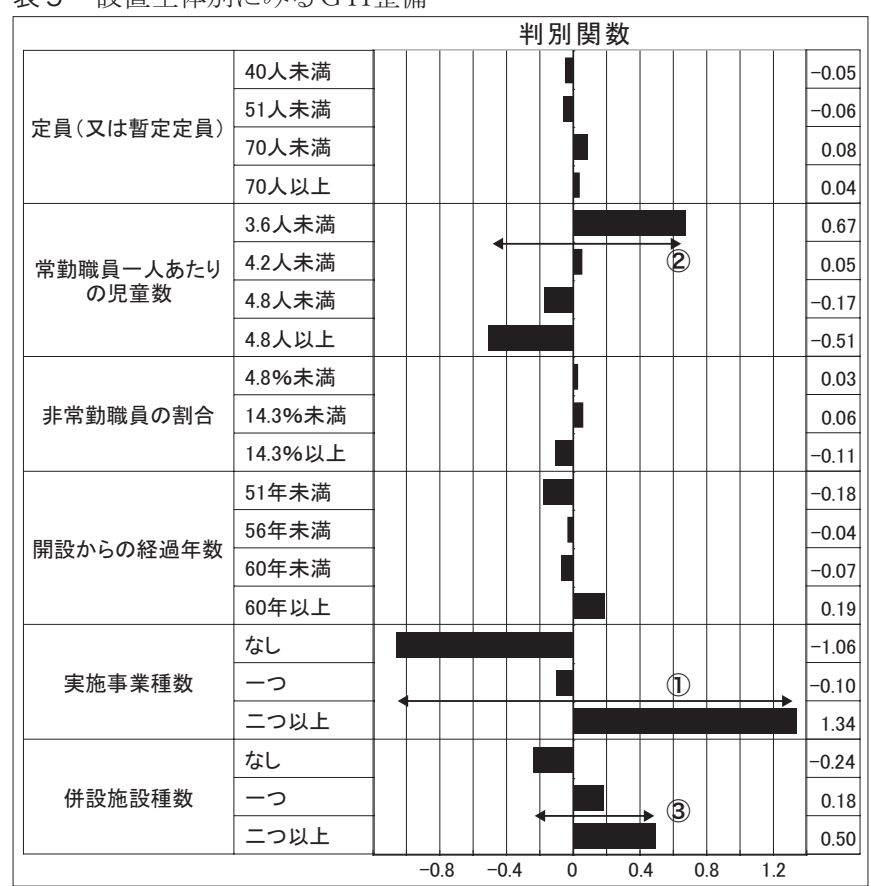

社会福祉法人 全国社会福祉協議会 全国児童養護施設施設協議会「平成 $17 \cdot 18$ 年 度全国児童養護施設一覧」より作成
にする高齢児童の支援に特化したものから、より広い児童を対象と したものに移行していると捉えることができる注7)。さらに、その事 業内容を整理すると、G H制度に本体施設の解体・小規模化の趣旨 が読みとれる東京都・横浜市の制度に対し、「地域小規模」や埼玉県 のそれにおいては施設規模の拡大が意図され、方向性には違いが見 られる注8)。「地域小規模」のみに着目寸ると、2001 年度以降に開設 した GHが、開設を見送っていた理由（表 3 ）に挙げたのは、土地 建物の取得と職員体制であった。一方、自治体からの認可において は東京都・横浜市とほかの自治体でひらきが見られる。このように、 全国に先駆けて G H 制度化を実施してきた東京都・横浜市と他の自 治体との方向性や整備には明らかな差が存在し、背景として自治体 の財政力の高さが推測される注9)。ゆえに本稿では GHの立地に関し、 東京都・横浜市（以下、東京・横浜と略す）とほか自治体という区 分を適宜用いる。

次に、GHの実施、非実施を本体施設の特色から明らかにすべく、 判別分析を行った（表 4,5 )。本体施設の実施事業種数や常勤職員 一人あたりの児童数、併設施設種数といった施設運営状況の影響を 見てとれる。本体施設の事業意欲や職員配置への配慮とGHの実現 可能性との関係を示唆する結果は興味深い。

\section{5. 生活集団の構成とその特性}

次に、職員と入所児童からなる生活集団の現状と構成をみた。

職員数は、平均で専属常勤職員が 2.1 名、その他の職員が 1.0 名 であり、担当職員数は 3 名注 ${ }^{10)}$ のものが最多である (図 2 )。実際の 職員数は「地域小規模」や東京都の制度上の 2.5 名を上回る值となっ ている。職員の年齢は 20 歳代が最多であるものの、児童養護施設全 体と比較すると 30 歳代と 60 歳代以上の職員が多く割り当てられて いる（表 6 )。更に勤務形態は、40 歳代以下職員の G H 専属常勤が

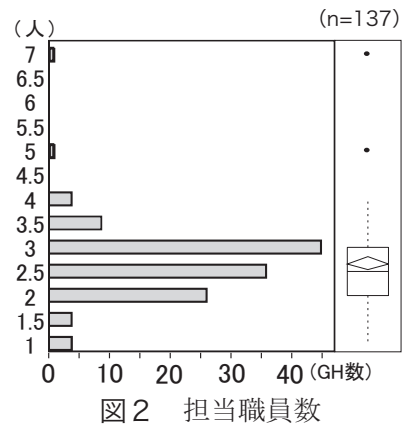

表 6 職員の年齢構成割合

\begin{tabular}{|c|c|c|c|}
\hline & \begin{tabular}{|c} 
児童養護 \\
施設
\end{tabular} & $\mathrm{GH}$ & \begin{tabular}{|c|} 
う専任 \\
常勤の割合
\end{tabular} \\
\hline 20歳代 & 50.7 & 44.7 & 73.8 \\
\hline 30歳代 & 20.9 & 24.9 & 81.7 \\
\hline 40歳代 & 16.7 & 13.9 & 67.3 \\
\hline 50歳代 & 9.9 & 10.2 & 54.1 \\
\hline 60歳代以上 & 1.9 & 6.4 & 36.4 \\
\hline 合計 & 100 & 100 & 100 \\
\hline
\end{tabular}

(職員数) $(n=113)$

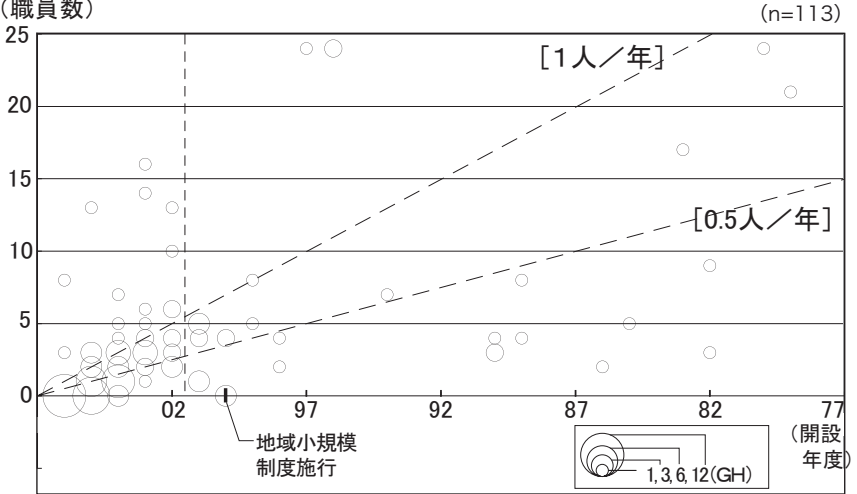

図 3 開設年と配置換え職員数 
$65 \%$ を越える一方、50 歳代、60 歳代以上と年齢が上がるにつれ専任 常勤の割合は減少しており、年齢や勤務形態を工夫しながら人員を 確保していることが伺える。勤務体制は通勤交替制が七割近くで採 用され、また約七割の職員は G Hの属する中学校学区の外から通勤 しているという実態が確認された。

2.5 名前後の職員から構成される GHではあるが、八割のGHでは 年に一人以上の職員の配置換えが確認された。それを開設年ごとに まとめる (図 3 ) と、02 年度以降に開設された G H は年に一人以上 の配置換えが行われるケースが $32.5 \%$ であり、それ以前に開設され た GHの $12.0 \%$ に比較して頻繁である。GH数が増加するにつれ、「特

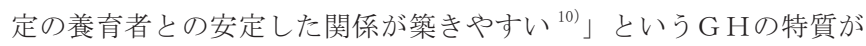
変容してきていることが推測される。

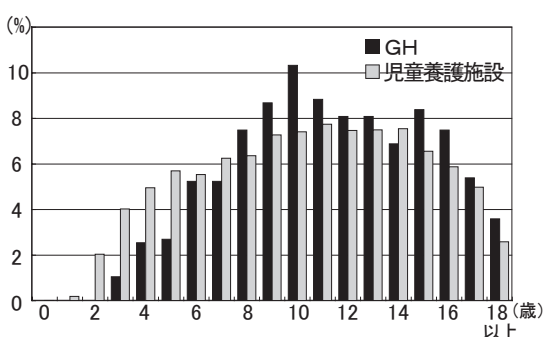

図 4 入所児童の年齢

児童養護施設の值は厚生労働省「平成 18 年社会福祉 施設等調查」より

\begin{tabular}{|c|c|c|c|c|}
\hline \multirow[t]{5}{*}{ 固有值表 } & & 固有値 & 寄与率 & 累積寄与率 \\
\hline & 第一主成分 & 3.44 & 21.53 & 21.53 \\
\hline & 第二主成分 & 2.14 & 13.35 & 34.88 \\
\hline & 第三主成分 & 1.72 & 10.74 & 45.62 \\
\hline & 第四主成分 & 1.60 & 10.01 & 55.63 \\
\hline
\end{tabular}

固有ベクトル

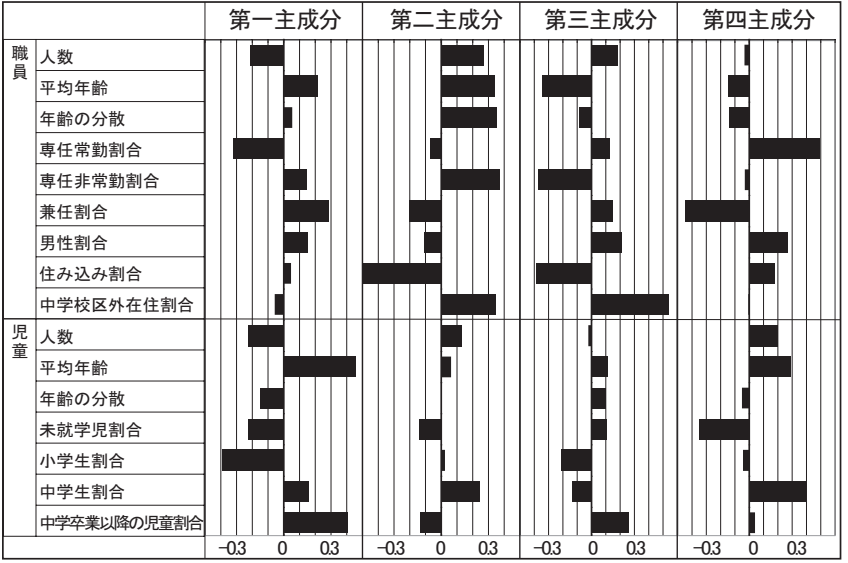

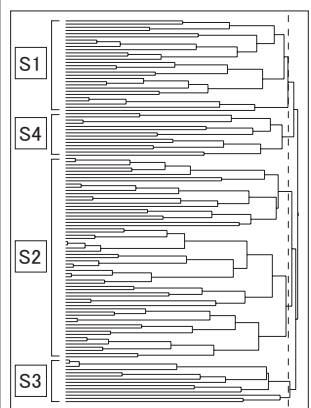

クラスター樹形図
表 7 入所児童数

\begin{tabular}{|c|r|r|}
\hline & GH数 & 割合 \\
\hline 2人 & 1 & 0.7 \\
\hline 3人 & 4 & 2.9 \\
\hline 4人 & 7 & 5.1 \\
\hline $5 人$ & 24 & 17.5 \\
\hline $6 人$ & 94 & 68.6 \\
\hline 7人 & 5 & 3.6 \\
\hline $10 人$ & 2 & 1.5 \\
\hline 計 & 137 & 100 \\
\hline
\end{tabular}

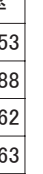


G H開設の障壁（表 3）として「職員体制の問題」と並びトップ に挙げられるのが「土地建物の確保」であるが、ここからはGHの 居住環境について、建物を中心に分析していく。

まず、G Hとして使用されるのは借家戸建て住宅が $63 \%$ 、次いで 持ち家戸建て住宅が $25 \%$ と、戸建て住宅が主体となっている（表 9 ）。 延心床面積は中央值が $119 \mathrm{~m}^{2}$ 、平均值は $130 \mathrm{~m}^{2}$ （図 6) であり、ま

表 9 建て方と所有形態

\begin{tabular}{|c|c|c|c|c|c|c|}
\hline & 持ち家 & 借家 & ほか & 計 & 割合 & \\
\hline 戸建て住宅 & 35 & 86 & 0 & 121 & 88.3 & \\
\hline 集合住宅 & 2 & 4 & 0 & 6 & 4.4 & \\
\hline 長屋 & 0 & 1 & 0 & 1 & 0.7 & \\
\hline 住宅以外を改築 & 4 & 2 & 1 & 7 & 5.1 & 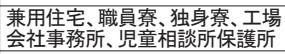 \\
\hline ほか & 0 & 2 & 0 & 2 & 1.5 & テラスハウス \\
\hline 計 & 41 & 95 & 1 & 137 & 100 & \\
\hline 割合 & 29.9 & 69.3 & 0.7 & 100 & & \\
\hline
\end{tabular}

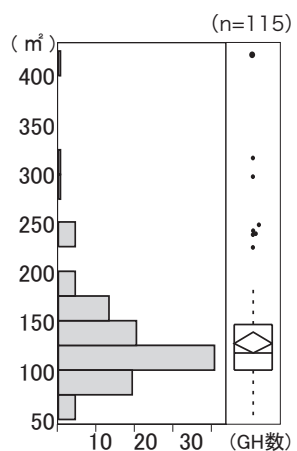

図 6 延べ床面積

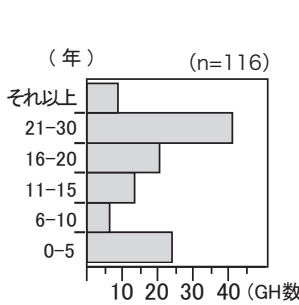

図 7 築年数

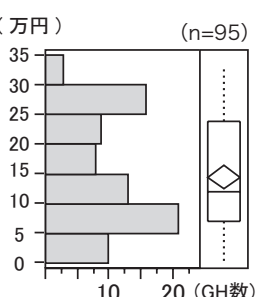

図 8 借家の家覒

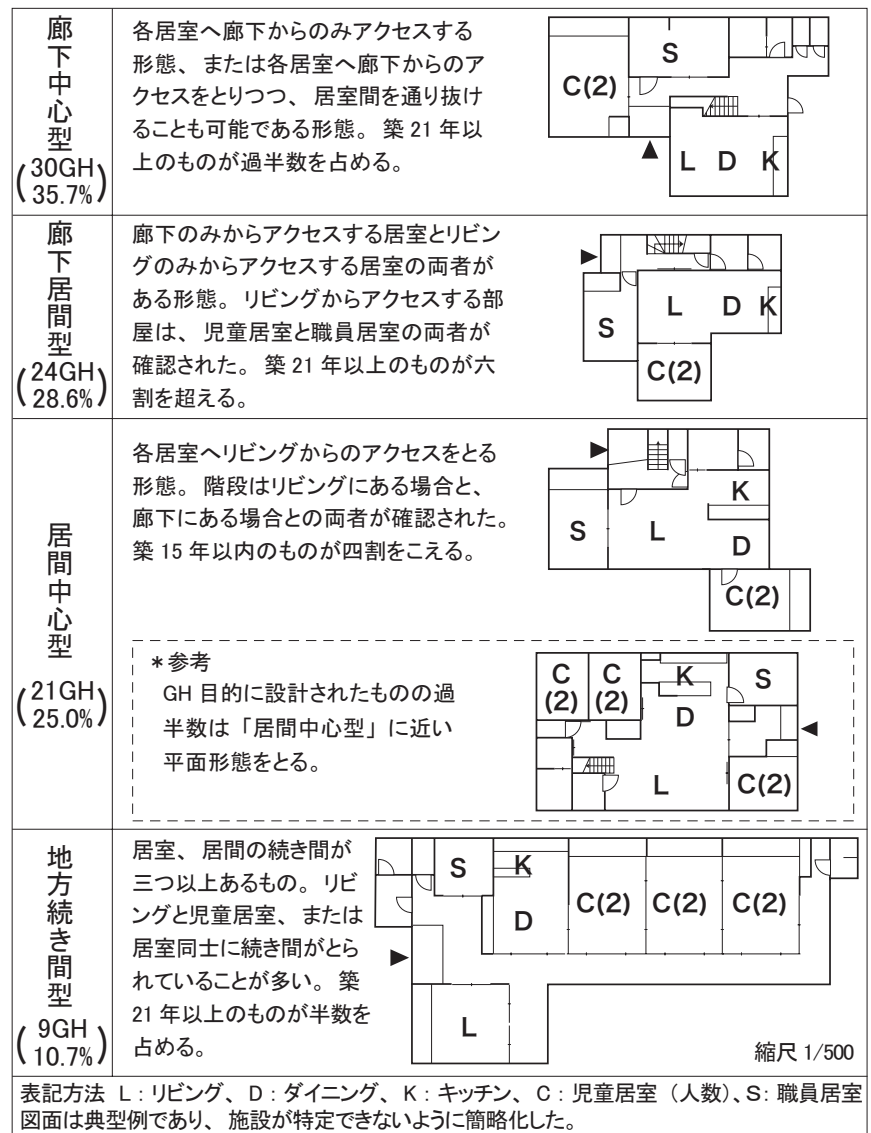

图面は典型例であり、施設が特定できないように簡略化した。

$$
\text { 図 } 9 \text { 借家戸建て住宅活用 } \mathrm{GH} \text { H平面類型 }
$$

た築年数、家賃ともにその分布には二つの極が見られる（図 7,8)。

六割強を占める借家戸建住宅は、その一階平面型から四つに分類 できる注11) (図 9 )。東京・横浜と三大都市圈注 12 ) では廊下中心型が 最多となる一方、地方続き間型はほとんど確認されなかった。また、 G H 目的に設計されたものは、児童と職員の共用空間がアクセスの 中心に据えられた型である居間中心型にあたるものが過半を占めた。 このように平面にはそれぞれ特色が見られるのだが、それらと生活 集団の類型や事業種との相関はみられなかった。

ここからは居住環境に関する指標について主成分分析を行い、全 体的な傾向をみた（図 10)。主成分の解釈はそれぞれ第一主成分を「借

\begin{tabular}{|c|c|c|c|c|}
\hline \multirow[t]{5}{*}{ 固有値表 } & & 固有値 & 寄与率 & 累積寄与率 \\
\hline & 第一主成分 & 5.68 & 14.94 & 14.94 \\
\hline & 第二主成分 & 3.47 & 9.13 & 24.07 \\
\hline & 第三主成分 & 3.11 & 8.17 & 32.25 \\
\hline & 第四主成分 & 2.60 & 6.85 & 39.09 \\
\hline
\end{tabular}

固有ベクトル

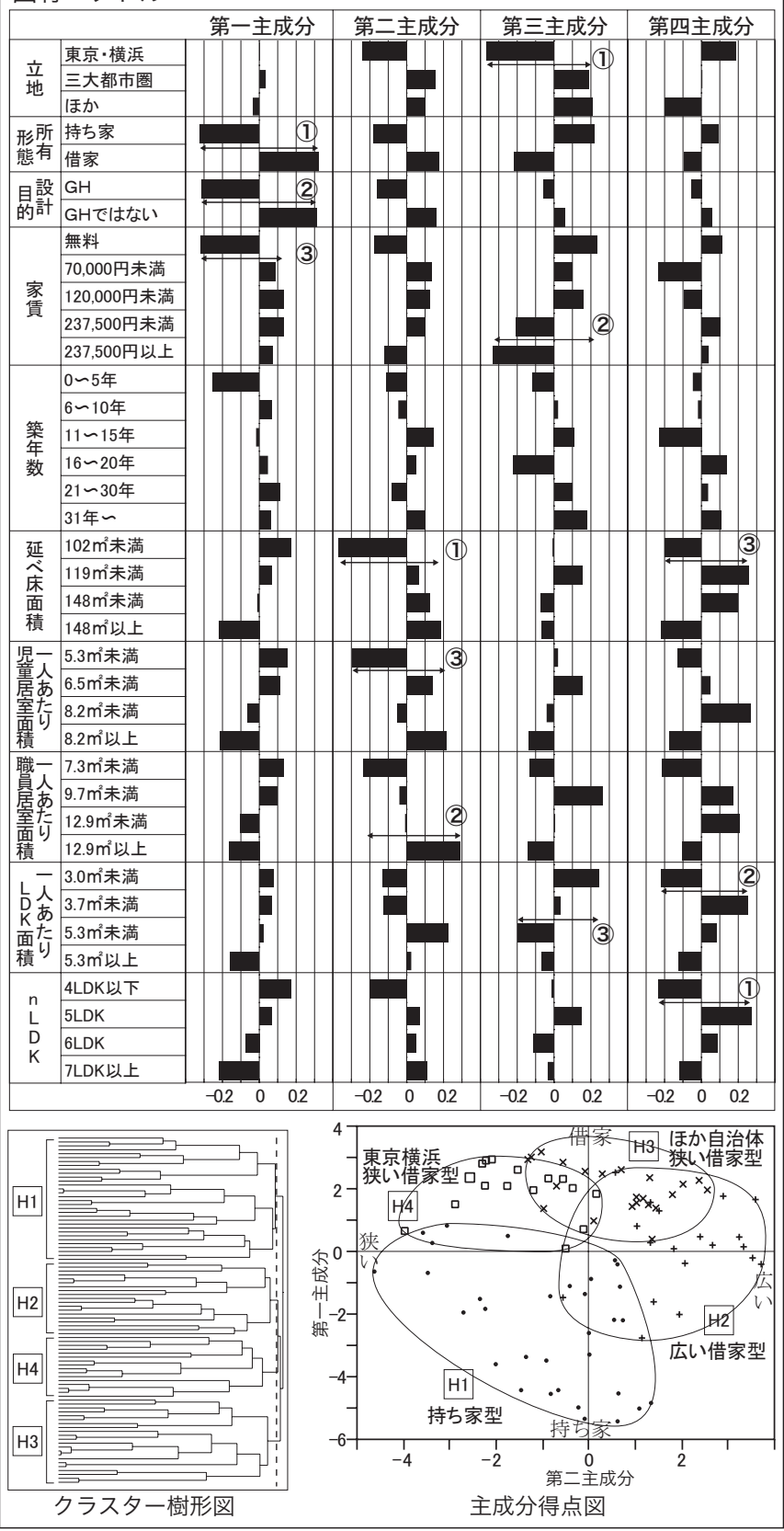

図 10 居住環境に関する分析 
表 10 居住環境類型の特性

\begin{tabular}{|c|c|c|c|c|}
\hline & $\begin{array}{c}\mathrm{H} 1 \\
\text { 持ち家型 }\end{array}$ & $\begin{array}{c}\mathrm{H} 2 \\
\text { 広い借家型 }\end{array}$ & $\begin{array}{c}\mathrm{H3} \\
\text { ほか自治体 } \\
\text { 狭い借家型 }\end{array}$ & $\begin{array}{c}\mathrm{H} 4 \\
\text { 東京横浜 } \\
\text { 狭い借家型 }\end{array}$ \\
\hline GH数 & 32 & 19 & 22 & 16 \\
\hline 東京横浜に立地する割合 & 37.5 & 47.4 & 0 & 93.8 \\
\hline 築年数5年以内の割合 & 37.5 & 10.5 & 0 & 18.8 \\
\hline 築年数21年以上の割合 & 31.3 & 21.1 & 68.2 & 43.8 \\
\hline 平均延べ床面積( m²) & 144.2 & 155.9 & 116.3 & 100.8 \\
\hline 家賃平均(円) & & 157,944 & 73,568 & 239,063 \\
\hline 一畳あたり家賃平均(円) & 0 & 1,778 & 1,127 & 4,118 \\
\hline
\end{tabular}

家か持ち家か」、第二主成分を「広いか狭いか」、第三主成分を「ほ かの自治体か東京・横浜か」、第四主成分を「中規模のGHか小規模 または大規模な GHか」を表す軸とした。次に第三主成分までの得 点值をデータとしてクラスター分析（データは標準化し、Ward 法を 用いた）し、四つの類型を得た（図 10）。各類型はその規模と所有形 態により H 1 は「持ち家型」 $(32 \mathrm{GH} 、 36.0 \%) 、 H ２$ は「広い借家型」 (19GH、21.3\%)、H 3 は「ほか自治体狭い借家型」（22GH、24.7\%)、 H 4 は「東京横浜狭い借家型」（16GH、18.0\%）と表現する。

各類型の特性（表 10）をみていくと、「持ち家型」は全国に分布し、 築 5 年以内のものが四割程度と全類型のうち最も高い比率で、平均 延べ床面積も $144 \mathrm{~m}^{2}$ と全国平均のそれを上回っている。「広い借家型」 （1畳あたり家貨平均 1,778 円）は延べ床面積が平均 $155 \mathrm{~m}^{2}$ と最大で あるが、「東京横浜狭い借家型」（同 4,118 円）と「ほか自治体狭い 借家型」(同 1,127 円 ${ }^{\text {i } 13)}$ ) の平均延べ床面積は前者が $100 \mathrm{~m}^{2}$ 、後者 が $116 \mathrm{~m}^{2}$ と全国平均を下回っている。またともに築 21 年以上が約半 数を占めている。

なお土地・建物選択の理由に「この場所しかなかった」と回答し たGHは、持ち家型」と「ほか自治体狭い借家型」では二割程度だが、 「広い借家型」では四割、「東京横浜狭い借家型」では五割を数えた。 条件によって、借家の確保が難しくなる状況が把握された。

\section{7. 類型ごとにみるグループホームの特性}

ここでは、これまで示した生活集団と居住環境の類型化の双方を 重初合わせて（図 11）、GH特性の全体的状況を把握する。

最も G H 数の多い「持ち家型」・「縦割り児童・通勤交替型」は、 半分が東京・横浜に立地しており、持ち家のなかでは規模は小さい。 「地域小規模」制度化以前に開設されたものが約半数を占めることも 特筆できる。同じ「持ち家型」でも、「小学生主体・住み込み型」と なると規模は大きくなり、東京・横浜の割合は低くなる。次に借家 であるが、「ほか自治体狭い借家型」は家賃の最も低いグループであ る。「縦割り児童・通勤交替型」を軸にしながら非常勤や住み込久職 員の活用など、運営面で工夫していることが推測される。「東京・横 浜狭い借家型」は、「小学生主体・住み込み型」の運営のうち $2 \mathrm{GH}$ が 2000 年より前に開設されているが、両者ともに開設 25 年を経過 寸る伝統ある G Hである。一方、「縦割り児童・通勤交替型」で運営 されるものは 00 年度以降の開設が九割強と、新設の傾向が強い。また、 同様の傾向が「広い借家型」・縦割り児童・通勤交替型」にもみら れる。「高齢児・住み込み型」は広い借家が主に活用されているものの、 平面図を見ると全児童への個室確保は難しいようだ。また、主に「自 活訓練事業」を用いて展開されるこのグループは職員数平均 2.0 名 と「地域小規模」や自治体制度の基準を下回るなかで運営される傾 向にある。

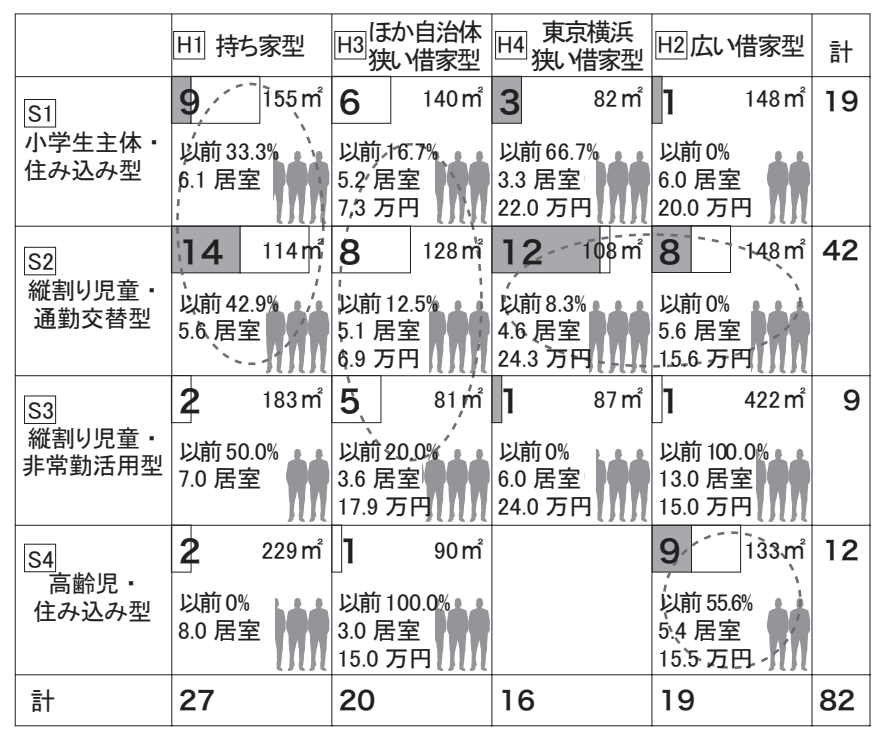

棒グラフはGHの所在地を表す（ $\square:$ 東京・横浜 $\square:$ ほかの自治体）

各ますの左上の数字は $\mathrm{GH}$ 数を、右上は平均延べ床面積を表す。

「以前 $\mathrm{x} \% 」$ 」地域小規模制度化以前に開設された GHの割合を、「y 居室」は平均居室数を、 $\Gamma_{\mathrm{Z}}$ 万円」は平均家賃を、人型は平均職員数を示す。

図 11 類型ごとにみるグループホームの特性

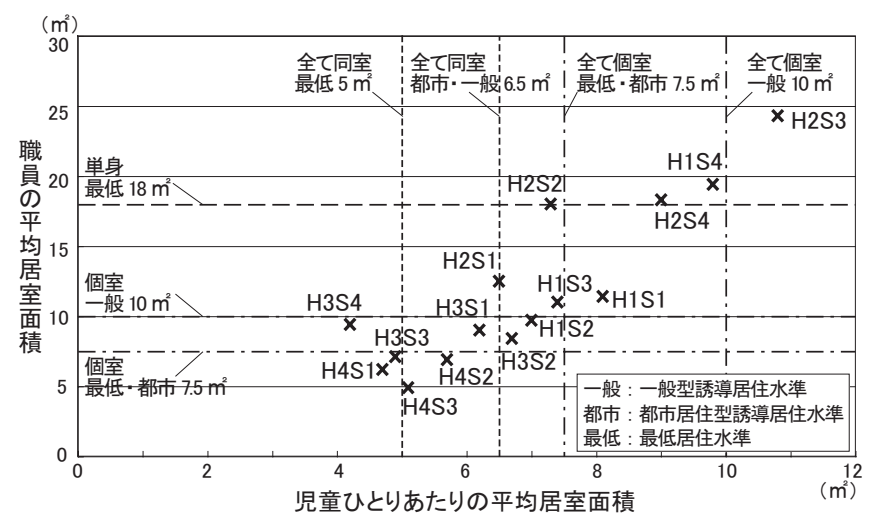

「同室」はふたりで一居室を使用する場合の、「個室」はひとりで一居室を使用する 場合の一人あたりの床面積。

図 12 類型ごとにみる居室面積

次に、児童および職員の居室面積の平均值と、住宅建設五箇年計 画に示される居住水準を比較注14) する (図 12)。児童居室においては、 全てを同室（ふたり一居室）としても一般型または都市居住型誘導 居住水準に満たない類型は六つあり、最低居住水準にも満たない類 型は三つ確認される。職員居室について最低居住水準に満たないも のが四類型確認された。児童への個室の必要性は改めて議論される 必要があるが、少なくとも高齢児や住み込み職員のプライバシー確 保といった面からも、児童、職員ともにかならずしも充分な居室面 積が確保されているとは言い難い状況が示された。

以上をまとめると、持ち家を確保してGHを運営できる施設が全 国にみられる一方、東京横浜以外の自治体では職員体制を工夫しな がら狭い借家のもとに G Hを展開している状況が明らかになった。 一方、東京横浜では借家を活用した「縦割り児童・通勤交替型」が 増加している。またそれ以外に、相応の環境確保が難しい高齢児対 象の $\mathrm{GH}$ H゙存在し、これら四つの系統が大きなかたまりであること が見てとれる。

8. まとめと考察 


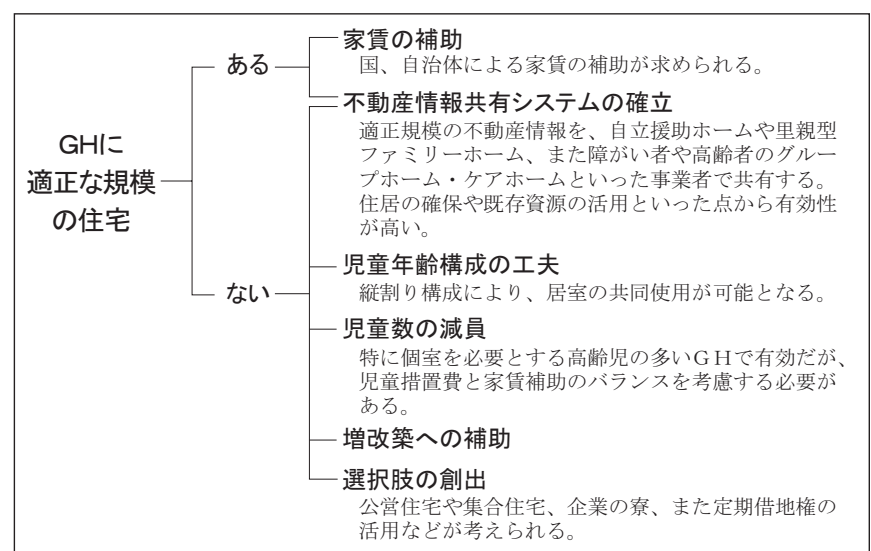

図 13 居住環境の確保・改善に向けた提案

以上、わが国の要養護児童を対象にしたグループホームの整備実 態について明らかにしてきた。以下にまとめと考察を続ける。

(1)これまで明らかにされていなかった全国におけるGHの整備実 態を包括的に明らかにするとともに、GHの実施には、自治体の児 童施策の方向性や財政事情、児童養護施設の運営状況といった複合 的要素の影響をみてとれることを示した。

(2) G H における生活集団の構成を、览童の年齢構成と職員の勤務 体制を特徵として類型化し、自治体や制度間の差異がありながらも 工夫した人員配置がなされていることを指摘した。また居住環境に ついては、生活集団の規模に比べて、必ずしも充分な面積が確保さ れているとは言い難い傾向を確認寸るとともに、その規模と所有形 態を指標とした類型化を通じて、施設や自治体によってその差が大 きいことを明らかにした。

(3) GHにおける生活集団と住環境の総合的な比較から、自治体間 の施策差や各種制度、地域の住宅事情や人員配置などが相互に影響 しながら、大きく四つの傾向が存在することを確認した。

(4)現在の GHの展開は「地域小規模」を中心に、複数制度の並立 のもとに行われた。これは、自治体の財政状況によっては、家賃負 担など実施施設の自助努力によりようやく成立する環境条件でもあ り、これまでは特に事業展開に意欲的な施設によって、G Hの展開 が担われてきた事象を裏づけるものであるとも言えよう。

こうした現況と同時に、土地建物の確保に課題を抱え、GHの開 設を見送ってきた施設の存在も確認した。従って、今後の G H 展開 において建築的立場としては、建物確保の障壁を低くし、またその 居住環境を改善する方策展開の重要性が指摘できよう注15)。以下、具 体的にいくつかの提案を示していきたい（図 13)。

まず $\mathrm{GH}$ 展開において、適正規模の住宅が存在する地域であるか 否かでその方向は異なってくる。存在する場合には、適切な家賃補 助並びに不動産情報共有システムの確立注 ${ }^{16)}$ などが有効な施策とし て考えられる。現在の地域福祉の潮流にあっては、福祉事業者がこ うした不動産情報を共有することは、既存資源の活用という面から も有効な手段となりうると思われる。しかしながら、民間の市場の中、 もしくは外でありながらもそれと共存しうるしくみをどのように位 置付けていくか、地域側の理解、行政側や福祉事業者からのインセ ンティブ等が必要となろう。

一方、適正規模の住宅のない地域では、まず入所児童の構成や定
員の再検討を視野に入れるべきと思われる。特に児童数の減員につ いては、それによる措置費の減額と、減員せず家賃補助費を負担す るケースとの比較検討がなされる必要がある。選択肢の創出といっ た点からは定期借地権の活用も有効なはずであるし、補助金の問題 により現在は展開が難しいとされているようだが、公営住宅等のス トック活用も選択肢のひとつであろう。

本稿により整備の実態とその特性を明らかにしたが、一方で地域 との関わりを重視するGHにとって、周囲の地域性や住民との関り は等閑視できない注 17)。今後は、そうした側面からの考察を進めてい くこととする。

\section{謝辞}

調查紙の回答および平面図の提供にご協力いただいた施設関係者 の方々、ご指導いただいた菅野實教授（東京電機大学）、坂口大洋助 教 (東北大学)、調查紙作成にご協力いただいた米川文雄氏（小松島 子どもの家)、藤田毅氏（仙台キリス卜教育児院）に感謝申し上げる。 なお、本研究は文部科学省科学研究費 (萌芽研究、代表: 小野田泰明、 共同研究者：本間敏行・徳川直人、課題番号 18656168）を受けたもの です。

注

注 1 ) 実際にわが国の児童家庭関係保障給付は、ここ20 年のあいだ社会保 障給付費全体の $3 \%$ 程度の推移を続けている ${ }^{17)}$ のが現状である。

注 2 ）参考文献 18、19 にそうした指摘がなされている。

注 3 ) 地域小規模児童養護施設では設備等に関する規定として運営要綱に 以下の三点が挙げられているのみである。((1) 日常生活に支障がないよ う必要な設備を有し、職員が入所している子どもに対して適切な援助及 び生活指導を行うことができる形態であること。(2) 一居室あたり 2 人 までとすること。(3) 居間、食堂等入所している子どもが相互交流する ことができる場所を有していること。)

注 4 ）調查紙における各質問項目に対し、無回答や回答ミス、また縮尺不 明の図面が認められたため、各図表に示される回答 G H 数（n）は異なる 值となっている。

注 5 ) 全国の児童養護施設数は 549 ケ所である。(2005 年 12 月全国児童養 護施設協議会調心゙)

注 6 ) 未成年人口のデータは平成 17 年国勢調査より。なお、堺市は当該デー タがなかったため割愛した。

注 7 ) 福祉行政関係者へのヒアリングからは、「自活訓練事業」に対する施 設からの評判の良さ、またそれと同時に児童の入所期間の制限 (上限 1 年) に対する批判が多く寄せられ、そうした事態が児童の入所期間に制限の ない「地域小規模」の設立へのひとつの契機になったことが確認された。 注 8 ) 近年、要養護児童の増加 ${ }^{20)}$ により、施設定員の拡大が求められてい るためである。むろん国では、本体施設における生活集団の小規模化を す寸めるべく、具体的には「小規模グループケア」事業を 2004 年より実 施してきてはいる。

注 9 ）地方公共団体の財政力を示す財政力指数をみると、東京都は $1.22 、$ 横浜市は 0.95 と高い值である。また東京都に次ぐ財政力指数を示す川崎 市（1.04）をあわせた三自治体は、自治体独自制度のもとで里親型 G H を最も意欲的に展開していることにも言及したい。なお、里親型GHは 全国の 8 自治体、34 カ所で実施されていることも今回の調查で確認され た。その一方、児童養護施設入所への措置権限を持つ児童相談所である が、各自治体での「未成年人口 10 万人あたりの児童相談所相談受付件数」 (平成 17 年国勢調查、平成 18 年度福祉行政報告例より算出）をみても、 東京都は上位 20 自治体にも入っておらず、横浜市に至っては最下位とい う状況である。他自治体に比べて養護ニーズが極めて高いとはいえない と考えられる。

注 10）その他の職員とは、専属非常勤職員、本体施設と兼任の職員、パー 
卜、他の勤務形態をとる職員を指す。また担当職員数は専属常勤職員を 1 名、その他の勤務形態の職員を 0.5 名として算出した。

注 11）参考文献 21、22 を参考に、各居室へのアクセス方法で分類した。

注 12）本論文では、三大都市圏に東京都・横浜市は含めないものとする。

注 13）総務省統計局「住宅・土地統計調査（平成 15 年)」によると、「ほ か自治体狭い借家型」と同程度の家賃水準にあるのは、公営借家（一畳 あたり家貨平均 1,127 円）や給与住宅（同 1,179 円）である。

注 14）ここでは、第八期住宅建設五箇年計画 ${ }^{23)}$ より、最低居住水準、都 市居住型誘導居住水準、一般型誘導居住水準における寝室面積と、最低 居住水準単身者の住戸面積をデータとして用いている。

注 15）財政難のもと福祉財源の削減が行われる昨今、少子化の影響により 特に児童家庭関係への給付費の減少が危惧される。しかし、例えば被虐 待児への支援を行うことは結果として、かなりの経済効果とそれに伴う 社会的費用の軽減が見込まれる可能性も示されつつあり ${ }^{24)}$ 、国や自治体 からの多角的かつ長期的視野に基づく支援制度が求められる。

注 16）アンケート調査の自由記述より、特に都市部において適正規模の住 宅と理解ある貸し主を探寸苦労が確認された。また、GHと同様に要養 護児童 6 名程度をケアする里親型ファミリーホーム従事者からも、居住 環境整備の難しさが聞かれている（第三回里親ファミリーホーム全国研 究協議会（2008 年 8 月）でのパネルディスカッションより)。

注 17）実際、览童養護施設入所児の家庭は貧困世帯であることが多いこと が指摘されている4)。それゆえ、どういった文化生活レベルを提供寸るか、 どういった地域を選定し、住民との交流を図るかといった議論は、なか なか公式の場で扱われない、しかし重要な課題であることが、複数の施 設関係者より指摘されてきている。

\section{参考文献}

1 ) 浅井春夫: 子どもの貧困克服のための政策試論, 浅井春男, 松本伊智朗, 湯澤直美編：子どもの貧困，明石書店, 2008

2) 広井良典：持続可能な福祉社会，ちくま新書, 2006

3 ）東京都社会福祉協議会児童部会リービングケア委員会編 : Leaving Care 巟童養護施設職員のための自立支援ハンドブック，社会福祉法人東 京都社会福祉協議会児童部会リービングケア委員会, 2005

4 ) Roger Goodman: CHILDREN OF THE JAPANESE STATE THE CHANGING ROLE OF CHILD PROTECTION INSTITUTIONS IN CONTEMPORARY JAPAN, Oxford University Press, 2000 ( 津崎哲雄訳：日本の児童養護, 明石書店, 2006)

5 ) 武川正吾 : 連帯と承認, 東京大学出版会, 2007

6 ) 西村昌記：新しい貧困とソーシャル・インクルージョン, 園田恭一 西村昌記編著：ソーシャル・インクルージョンの社会福祉, ミネルヴァ 書房, 2008

7 ) 今田高俊: 福祉国家とケアの倫理, 塩野谷祐一, 鈴木興太郎, 後藤玲 子編 : 福祉の公共哲学, 東京大学出版会, 2004

8 ）厚生労働省社会保障審議会福祉部会：市町村や地域福祉計画及び都道 府県地域福祉支援計画策定指針の在り方について, 2002

9 ）芹沢俊介：「新しい家族」のつくりかた , 晶文社, 2003

10）社会的養護の今後のあり方に関する研究班 : 社会的養護の今後のあり 方に関寸る研究ーグループホーム養育に関する内外調査研究一, 資生堂 社会福祉事業財団, 1986

11）天羽浩一：児童盖護施設分園型グループホームの現状と今後の課題, 福祉社会学部論集 Vol.22 No. 2, pp. 37-50,2003.10

12）石垣文, 菅野實, 小野田泰明, 坂口大洋 : 情緒障害児一の環境療法 の展開にみる小舎型施設空間の意味, 日本建築学会計画系論文集 No. 582 , pp. 17-23, 2004. 8

13）小野田泰明, 菅野實, 針生承一, 本間敏行, 大林政夫, 瀬戸信太郎 : 養護施設のリニューアルにおける建築計画的実践, 日本建築学会技術報 告集，第 3 号, pp. 212-216, 1996. 12

14）全国児童養護施設協議会・制度検討特別委員会小委員会：子どもを未 来とするために, 2003

15) 高橋利一, 加藤尚子: 児童養護施設における小規模化に関する調査研究, 日本社会事業大学研究所年報 36 巻, pp. 141-186, 2000. 12

16）庄司順一ほか：グループホームの現状と課題（1）, 日本子ども家庭総
合研究所紀要第 39 集, pp. 83-149, 2003.8

17）国立社会保障・人口問題研究所. 平成 16 年度社会保障給付費.2006, （オン ラインデータベース), 入手先〈http://www.ipss.go.jp〉, (参照 2007-04-07).

18）金子勇：少子化する高齢社会, NHK ブックス, 2006

19）池本美香：失われる子育ての時間, 勁草書房, 2003

20）厚生労働省：今後目指すべき児童の社会的養護体制に関する構想検討 会中間とりまとめ 別添資料, 2007

21）鈴木成文：住まいを語る，建築資料研究社, 2002

22）服部岑生：平面類型から見た住様式の動向に関する研究 (1), 住宅建 築研究所報 Vol. 7, pp. 87-116, 1980

23）国土交通省住宅局住宅政策課監修, 住宅政策研究会編：新世紀の住宅 政策，ぎょうせい, 2002

24）京極高宣：社会保障は日本経済の足を引っ張っているか, 時事通信出 版局 , 2006

（2008年10月10日原稿受理，2008年12月 9 日採用決定） 